\title{
6. Precedence in the Formation of the Domain of Wai Brama and the Rajadom of Sikka
}

\section{E. D. Lewis}

\section{Introduction}

The regency of Sikka in east central Flores is an ethnological laboratory in miniature for the study of differentiation in Austronesian societies. Except for an enclave of Lamaholot-speakers in north-eastern Sikka, a Lionese population in the district's west and small communities of immigrants from Sulawesi on the shore of Maumere Bay, all of the peoples of the regency of Sikka speak dialects of a single language, Sara Sikka, and possess a common cultural heritage. Nevertheless, the district's Sikkanese population includes communities whose patterns of social organization are quite distinctively different from one another. The most striking differences are those between the people of Tana 'Ai (most especially the ceremonial domain of Tana Wai Brama) in the mountainous eastern region of the district, the Ata Krowé of the regency's central and north coastal regions, and the Ata Sikka, the people of the south coast of the regency between Léla and Bola. ${ }^{1}$

The people of Tana Wai Brama are divided into five principal clans, each of which is made up of a number of houses. The people of Wai Brama reckon descent through women and each of the houses thus consists of people whose kinship is through consanguineally related women. Both the clans and houses of Tana Wai Brama are ranked in terms of the precedence of their founding ancestors and precedence informs activities in every realm of social life. Perhaps because of its relative remoteness, until the early 1990s and in contrast to the peoples of the central and coastal regions of Sikka, Tana Wai Brama and Tana 'Ai generally did not have intensive contact with outsiders. The people of Tana Wai Brama thus maintained their patterns of social order and exchange to a greater extent than other peoples of east central Flores.

By comparison, many communities of central Sikka have for centuries participated in trade and have been open to the movement in and out of the region of people of different cultures. Furthermore, until the decade following the end of World War Two, Krowé and Sikka were an indigenous rajadom under a ruling house in Sikka Natar, the south coast village of Sikka, one of many petty states found in eastern Indonesia. In historical times, the people of Sikka Natar were influenced by the Portuguese in the archipelago perhaps more than other 
communities of east central Flores. In the nineteenth century, the whole of Flores became subject to Dutch rule.

The interplay of their common cultural heritage and different histories produced social systems in Tana Wai Brama and the rajadom of Sikka that offer intriguing possibilities for studying social differentiation and, specifically, precedence and hierarchy, in closely related communities. But any attempt at comparison is confronted by certain challenges and difficulties. The challenges arise from the question of how the two societies diverged in the first place and whether or not, after they diverged, different historical processes were at work in the two societies. If there were, then the divergence of the two societies through time can be understood in terms of those processes and the principles of their common culture.

The difficulties arise from the requirement that there be sufficiently dependable historiographic and ethnographic material available to make such a comparison possible in the first place. Historiographic sources on Sikka are scarce and for Tana Wai Brama almost non-existent, unless we admit as evidence the oral and mytho-historical traditions of both peoples which are available from ethnographic research in the district. This is what I intend to do here.

The peoples of the domain of Tana Wai Brama in the mountains of Tana 'Ai and the village of Sikka Natar (the original seat of the Rajadom of Sikka) on the south coast of east central Flores both possess complex mythic histories that recount the origins of their societies in the coming together of groups of immigrants from many different places of origin. In Tana Wai Brama, the myths of origin are recounted orally on occasions of ritual. In Sikka, the histories are no longer told as a coherent body of myth on ritual occasions, but literary versions of the myths survive in manuscripts written by two Sikkanese authors between 1925 and $1960 .{ }^{2}$ As the tales are told in the myths of the two societies, the Rajadom of Sikka and domain of Wai Brama evolved quite differently, but analysis of their mythic histories reveals themes and logics of history sufficiently similar to demonstrate an allopatric relation between the two. I will show how the Ata Tana 'Ai and the Ata Sikka use common themes and logics to account for the origins of quite different societies.

According to the mythic histories of its people, the domain of Wai Brama was formed from the sequential arrival of groups of immigrants. Each group was incorporated into the ceremonial system of the domain and the descendants of each group make up the clans that comprise the society today. The mythic history of Sikka Natar also recounts the arrival of groups of immigrants whose descendants make up the major groups of the contemporary society and to whom those groups trace their origins.

Sikka's myth of origin relates that two ships sailed from the west and landed, one after another, near the site of the contemporary village of Sikka. The crew 
of the first ship travelled inland, where they took up residence. A son of the captain of the second ship married an autochthonous woman and their descendants became the rajas of Sikka. ${ }^{3}$ In contrast to Tana Wai Brama, after its formation, Sikka Natar became the centre of a rajadom, an expanding petty state over which the ruling house of Sikka exercised political dominion. The expansion of the Rajadom of Sikka involved the incorporation of subaltern negeri ('nations', that is, the villages of the region) in central Sikka into a single polity ruled by Lepo Geté, the 'Great House' of the rajas of Sikka. In contrast to Tana Wai Brama, the pattern of polity formation in Kerajaan Sikka (the Rajadom of Sikka) was thus one of the sequential incorporation of other communities by the geographical expansion of the polity.

Contrary to the sound advice of a respected mentor, I shall begin this essay with a disclaimer. I had intended this essay to defend a simple enough thesis, which is: whereas the society of the people of the domain of Wai Brama in Tana 'Ai is ordered by principles of precedence, that of the people of Sikka Natar and the rajadom through which their ancestors came to rule over most of the district of Sikka was ordered by hierarchy. In setting out the argument for this thesis I had thought, firstly, to add weight to arguments I have made elsewhere about the social organization of the Ata Tana 'Ai. Secondly, I wished further to develop observations I have made in print (Lewis 1996a) regarding the organization of authority in Kerajaan Sikka. Thirdly, I aimed to show that precedence, as a principle of social organization clearly at work in both Tana Wai Brama and Sikka, can manifest itself as hierarchy in certain circumstances, such as those in which the Rajadom of Sikka evolved. By showing that Tana Wai Brama is a society ordered by precedence in an historically uncomplicated form, whereas the Sikkanese rajadom, while founded in precedence, became a hierarchically ordered society, I intended to suggest that hierarchy does not accord in all societies with the general theory of hierarchy proposed by Dumont (1980), and that hierarchy can arise from sources other than the 'encompassment of the contrary'.

In pursuing these aims, I first encountered difficulties with the material available on the history of the Rajadom of Sikka. Then, in 1994, a corpus of more than 100 manuscripts composed by two Sikkanese writers came to light in Maumere. The large collection of papers greatly supplemented a single book length manuscript that had come into my possession in 1977. The information on Sikka's history and the myth of origin of the Sikkanese ruling dynasty contained in the manuscripts allows elements of precedence and hierarchy in the culture and society of the Sikkanese rajadom to be explored with the domain of Wai Brama as a comparable case. However, taking into account the literary evidence, the proposal that Wai Brama is a society ordered by precedence whereas Sikka was a society ordered by hierarchy is too simple to sustain. 


\section{Boer's and Kondi's Hikayat Kerajaan Sikka}

Shortly after World War Two, Dominicus Dionitius Pareira Kondi, an Ata Sikka and an official in the government of the last raja of Sikka, completed an 86,000 word history of the rajadom. Somewhat earlier, his age-mate and fellow government official, Alexius Boer Pareira, completed exhaustive notes on the rajadom's myth of origin. Boer and Kondi began their careers as members of the small cohort of Sikka's first school teachers before raja Don Thomas da Silva drafted them into government service in the 1920s. Taken together, Boer's and Kondi's long manuscripts and some 100 additional documents in their handwriting comprise the Hikayat Kerajaan Sikka. The works were composed mainly in archipelagic Malay, the language of commerce and school tuition in Indonesia before the nation's independence, but include long transcriptions of Sikkanese ritual speech, the genre of Sara Sikka (the language of Sikka) in which Sikka's origin myths were once narrated orally. ${ }^{4}$

The first part of the Hikayat is a compendium of the mythic histories of Sikka and includes long narratives in the ritual language of Sikka. Boer and Kondi present the myths as a factual history of the origins of the rajadom. It is from the Hikayat and my own field notes from Sikka that I draw information for this essay.

The Hikayat Kerajaan Sikka is divided into four main parts. The first is a brief introduction in which Kondi identifies the 36 suku bangsa (BI 'tribes') ${ }^{5}$ from which the people of Sikka originated and sets out their origins from places as diverse as other regions of Flores and 'Siam' and 'Hindia Belakang'. ${ }^{6}$ The second part of the Hikayat is entitled 'Dewasa yang Pertama' ('The First Period') and is subtitled 'The history of the creation of the Rajadom of Sikka'. It is an account of a series of lineally related mo'ang geté (SS big men) who led the various communities of the Ata Sikka and who began extending their influence over other negeri by travelling about the region appointing tana pu'ang (SS 'sources of the earth') and establishing laws pertaining to religion in the period before the introduction of marriage, birth rituals, the settlement of disputes and Catholicism. This part of the work culminates with the dispossession of the people of Hokor and the seizure by the Sikkanese of their village, which became the contemporary Sikka Natar from which the rajadom expanded.

The third section of the Hikayat recounts the life of Don Alésu da Silva. Don Alésu journeyed to Malacca, where he met raja Worilla, the raja of Malacca, under whose sponsorship Alésu was educated in 'ilmu politik' (BI 'political science', 'politics'), that is, government, and the precepts of the Catholic Church. Before he returned to Sikka, Alésu sent Augustinyu da Gama, a son of raja Worilla, to become the first teacher of religion in Sikka. The Hikayat details Don Alésu's consolidation of the various negeri of Sikka into a single polity, which occurred in conjunction with the conversion of all of the people of the rajadom 
to Catholicism. ${ }^{7}$ Here the work tells how Alésu went about east central Flores creating alliances with leaders in the negeri of the region and, in many cases, raising up leaders in communities which had none before. With each alliance, Alésu established his own prior position by delegating authority over local matters to his new allies. The alliances were sealed by gifts of elephant tusks and other items of ceremonial wealth from Alésu to the leaders of each of the communities in turn. Augustinyu da Gama figures centrally in this part of the narrative. Da Gama's name is significant in itself, for it accords with the Sikkanese term for religion (that is, Catholicism), which is the Malay and Indonesian word agama, 'religion'. As a teacher of religion, da Gama brought Catholicism to Sikka. While recounting the creation of the Sikkanese polity in considerable detail, the Hikayat thus also charts the origins of the relationship between the rajadom and the Church in Sikka, and represents that relationship as one whereby the raja is prior and the Church of derivative or delegated precedence in the larger scheme of the rajadom (see Lewis 1998b).

The narratives of the 'Introduction', 'The First Period' and the early parts of 'The Second Period' have the character of myth and are undoubtedly written versions of the oral mythic histories of Sikka, ${ }^{8}$ but Boer and Kondi refer to them as sejarah (M, BI 'history').

The bulk of Boer's notes concerns Sikka's mythic past while the fourth and last part of Kondi's manuscript consists of accounts of events in 'historical' times and deals with the period of the Dutch presence in the rajadom from the middle of the nineteenth century to World War Two. Here Kondi's manuscript includes simple chronologies of events and reproduces official documents of the period to which he had access as an official in the raja's government. This last section is unmistakably 'history' in the common sense of the term rather than myth. But the transition from the one to the other is gradual and is not signalled by Kondi himself in any way. There is simply a subtle shift in the narrative from a written down form of mythic history to a form of documentary history which deserves the most careful textual analysis.

The Hikayat Kerajaan Sikka is structured as a chronology of persons and events. These are undated in 'The First Period'. The dating of persons and events begins in 'The Second Period', in which some of the figures are, without question, historical persons while others may or may not have been. So, too, the events that Boer and Kondi recount. Those of the later period covered by the Hikayat were historical events and for some of them we can find corroborative evidence in documents such as the diaries (D dagboeken) written by the controleuren or posthouders, the Dutch colonial officials who lived in Maumere from the 1870s to 1942 , when Maumere was occupied by the Japanese army. ${ }^{9}$ Other events, such as Don Alésu's journey to Malacca, have the character of a mythic quest and whether or not there was a Sikkanese who travelled to Malacca and there 
met a raja named Worilla has proven resistant to verification by means of independent documentation. ${ }^{10}$

It is perhaps a logical necessity that all histories must start with persons and events and it is difficult to conceive of a history that does not in some way relate the one to the other. What is striking, but by no means unique (one can cite histories of European monarchies in which genealogy orders history and quarrels over succession are major events), about Kondi's history is that the main characters (excepting, of course, their antagonists) are persons who are related genealogically as ascendants and descendants to each other through time. Furthermore, there is an implicit assumption in Boer's and Kondi's writing that the events which chart the history of the creation of the Rajadom of Sikka are at least partly a consequence of the genealogical relatedness of the rajas, the protagonists in their narrative. In other words, it is not merely that the big men and rajas, whose tale the Hikayat is, are related, but that the fact of their relatedness lent extra force to the events by which the history is charted. Indeed, one view which can be taken of the Hikayat is that it is a document that justifies the claims of Lepo Geté, the Sikkanese royal house, to the authority to rule and its members' claims to status as rulers in terms of genealogy (see Lewis 1999). The individual persons of the tale are thus members of a central corporate group within which power is held and among whom political authority and rights to power are transmitted through time.

The royal genealogy of Sikka identifies 18 rajas who follow a succession of 11 big men, in all 29 persons who held authority in Sikka through 19 generations, according to one version of the genealogy. ${ }^{11}$ These rajas were:
I. * Mo'ang Igor
II. * Baga Ngang
III. * Mo'ang Alésu
IV. Mo'ang Kapitang
V. Du'a Maria
VI. Mo'ang Samao
VII. * Dona Ines
VIII. Mo'ang Sikukoru
IX. Mo'ang Juan Iku

X. * Mo'ang Mbako I Kikir Hiwa

X. ${ }^{*}$ Mo'ang Mbako I Kikir Hiwa
XI. Mo'ang Prispin
XII. * Don Luis
XIII. * Mo'ang Mbo
XIV. * Mo'ang Andreas Jati
XV. * Mo'ang Mbako II
XVI. * Nong Méak
XVII. * Mo'ang Thomas
XVIII. * Mo'ang Sentis

The asterisked names are those of persons whose careers and times Boer and Kondi treat at length or at least mention and it can be seen that six of Sikka's rajas are not dealt with in the Hikayat.

The persons whose lives and activities are the subjects of major chapters include, from 'The First Period', Mo'ang Bata Jawa. This paper consists mostly of a text in Sikkanese ritual language that recounts how Bata Jawa went about 
the district of Sikka designating tana pu'ang ('sources of the earth') who would thenceforth exercise ritual authority in each negeri of the region. Next comes Bata Jawa's son, Mo'ang Baga Ngang, a warrior whose power extended throughout much of central and eastern Sikka. Baga Ngang went around the district appointing secular leaders in each of the negeri. ${ }^{12}$ Kondi recounts his activities in considerable detail. It was Baga Ngang who usurped the village of the Hokor people and made it the centre from which he exercised his power over the region, thereby setting the stage for the creation of the rajadom. The main figure in the early chapters of 'The Second Period' is Mo'ang Don Alésu, Mo'ang Baga Ngang's son. Don Alésu travelled to Malacca, returning to Sikka with a knowledge of government and the Catholic religion.

Several events, which Boer and Kondi clearly view as crucial to the shaping of the rajadom and the powers of its rajas, are recounted in some detail in the Hikayat. The first was a rebellion in north Sikka during the reign of raja Andreas Jati in the second half of the nineteenth century. The second was a rebellion led by a man named Teka and the raja's war against Teka and his followers which ensued. The third was a rebellion, led by a woman named Du'a Toru, by people in Tana 'Ai. The Hikayat ends with an account of events during the Japanese occupation, Sikka's role in the formation of the Republic of Eastern Indonesia, and the death of raja Don Thomas Ximenes da Silva in 1954.

The Hikayat is, in part, a chronology of events. Beyond that chronology, consideration of Boer's and Kondi's texts shows the ways in which the Sikkanese rulers represented their history and legitimated their authority. These they did not in terms of a logic of events ('historical' or otherwise), whereby event $A$ gives rise to situation $X$, in which event $B$ occurs, which results in situation $Y$..., but in terms of culturally given metaphors and a logic of myth. The metaphors and the logic by which they are articulated not only predated the clearly historical events recounted in the last chapters of the Hikayat, but can be seen at work in contemporary Sikka and neighbouring societies such as Tana 'Ai. Indeed, the metaphors and logic of the Hikayat are what bind the discrete events recounted in the text into a consistently coherent narrative. Causality as a linkage between events is notably absent from the structure of the narrative.

In the text we can see a construction and legitimation of social hierarchy through mytho-historical precedence. But, as Fox (this volume) points out, in addition to underpinning discourses of social order, precedence must do things, which is a way of saying that myth and history, to be meaningful, must have effect in the contemporary life of a community. In Tana Wai Brama, precedence, as a theory of the past, orders contemporary exchange between major social groups and the persons who act in ritual. In Sikka, precedence legitimates a political and social order, the core of which was Lepo Geté, the house of the rajas. 


\section{The Common Origin of the Ata Sikka and Ata Tana 'Ai}

The Hikayat begins with accounts of the arrivals of two groups on the south coast of Flores, near the contemporary Sikka Natar. Both groups came by sea, from distant places to the west. The descendants of the first immigrants came to be known as Sikka's autochthons, while the descendants of the second ship would become Sikka's rajas. While the first group were immigrants, as the myth relates, they were predecessors of the second ship's company who also landed near Sikka Natar. By the logic of precedence, they were more autochthonous than the later newcomers and are represented as orang asli (BI original people) in the Hikayat. With respect to the arrival of the first newcomers, the Hikayat relates two couplets of ritual language, the language of myth in Sikka, followed by a brief comment:

Wawa Siam mai

Siam sipa jong wutung

Sipa jong wutung

Léma Nidung Magé Gahar
[They] came from Siam

Skilfully sailing their ship from Siam

Skilfully sailing their ship

They landed at Nidung Magé Gahar.

It is evident they came from Siam by prau or ship and landed at Nidung Magé Gahar (between Sikka and Léla, between Ili Lewa and Napu Nao). They later moved to Mekeng Detung, to Iling Bekor, and then lived there. Because they were not healthy there, they then moved to Wolo Laru Poma Pihak Watu Daring in Mekeng Detung. ${ }^{13}$

Leaving aside the questions of how Kondi knew that the Sikkanese originated from 'Siam' (Boer's notebook has them arriving from 'Benggala' [Bengal]) and whether or not they did in fact, this passage from the Hikayat is nonetheless interesting on a number of points.

Firstly, the people who would become Sikka's autochthons were not autochthonous, but came from overseas. Secondly, they landed at a place on the south coast of Flores near Sikka Natar, which, in the later history of Sikka, would become the seat of the rajadom, but did not occupy the south coast. Instead, they moved inland to Mekeng Detung, a place near Ili Bekor, one of a range of mountain peaks in central Sikka. ${ }^{14}$ Later in the Hikayat, Boer and Kondi recount the tale of how Mo'ang Baga Ngang captured the site of Sikka Natar from the people known as Hokor, who were then forced to flee eastward. The ngeng ngérang, the mythic histories of the people of Tana Wai Brama, name Mekeng Detung as the place of origin of Hading Dai Dor and Uher La'i Atan, the brothers who were the ancestors of Ipir Wai Brama, the 'source' (that is, founding) clan of the domain of Wai Brama. In the mythic histories of Wai Brama, Hading and Uher 'bubbled up' from a hole in the ground in Krowé, at Mekeng Detung, and from there set out on a search for uninhabited land which led them to Tana Wai 
Brama (see Lewis 1988a:53ff., 1988b). Wai Brama's founders were thus of Sikka's autochthons. In the mythic histories of Tana Wai Brama, their origin is recounted as follows:

Bekor a'un wawa 'ia

Bubuk a'un wawa é

Wawa Krowé Kléga inan

Wawa Lépak Marin aman

Mekengdetung Woloarung ${ }^{15}$

Popo Piak Watu Darin
My rising was over there (in the west),

My bubbling forth was over there,

(My) mother was there in Krowé Kléga,

(My) father was there at Lépak Marin,

At Mekeng Detung Woloarung

At Popo Piak Watu Darin (Lewis 1988a:53).

Thus the mythic histories of both Sikka and Tana Wai Brama identify Mekeng Detung as important in the origins of these two peoples, for the one as the first place of settlement of newly-arrived off-shore immigrants and, for the other, the place of origin of founding ancestors who are said to have 'bubbled forth' from the earth at a place some distance from where they eventually established a new domain. If we juxtapose these two myths, it can be said that the origins of the Ata Tana 'Ai and the Ata Sikka are closely linked, if not common, a point readily made by contemporary Ata Sikka and Ata Tana 'Ai themselves.

\section{Precedence in Tana Wai Brama}

Much of my research in Tana Wai Brama has addressed questions about social and ceremonial hierarchies and the way that social organization and daily social life are informed by what some anthropologists working in eastern Indonesia have come to refer to as precedence. In the most general terms, precedence is the ordering of persons or a set of things in terms of a sequence of past events which brings those persons or things into ordered relationships. As the term has come to be used in analyses of social structure in eastern Indonesian societies, precedence is the ordering of social groups and the relationships of their members in terms of the temporal sequence in which those groups were (or are thought to have been) founded. In Wai Brama, the precedence of clans is encoded in the mythic histories of the founding of the domain, the main ceremonial and political domain in the mountains (see Lewis 1988a).

Tana Wai Brama is one of seven ceremonial domains into which Tana 'Ai, the mountainous eastern region of Kabupaten Sikka, is divided. The mythic histories of the domain recount the discovery of the forests and mountain valleys of Tana Wai Brama by two brothers, Hading Dai Dor (the elder) and Uher La'i Atan (the younger), who set out from Mekeng Detung in central Sikka to find empty land suitable for settlement. Hading and Uher became the founders of sukun (clan) Ipir Wai Brama, each the ancestor of one of the two branches into which clan Ipir is divided today. Ipir Wai Brama thus became the founding clan of Tana Wai Brama, which people today describe as the 'source' and 'central' clan of the 
domain. Over time, other people arrived in Tana Wai Brama. The discrete groups of newcomers were the ancestors of the people of clans Tapo, Mau, Magé and Liwu which, with clan Ipir, are today the five main clans of the domain.

As they arrived, each of the ancestors of the four subaltern clans of Tana Wai Brama received land for gardens from clan Ipir and were vouchsafed rituals to perform and a status in the oda geté (SS great precedence) of the domain. By virtue of these statuses and responsibilities in the ceremonial system of the domain, each clan is ranked in relation to the others in terms of the sequence in which the clans' founding ancestors arrived in Tana Wai Brama. Each clan thus has a position in the community which derives from the oda ('precedence') of clans in the domain. The oda of a clan informs the relationships of its members to people in other clans in the realms of ritual performance, alliance and exchange. I have elsewhere explored the internal organization of the domain of Wai Brama and the ways in which the conception of precedence orders relationships of clans, houses within clans and persons in ritual performance. ${ }^{16}$

For purposes of comparison with Sikka, I need only identify here in the most general terms the structure of the domain as it is represented in the mythic histories. That structure is one in which a ceremonial domain, which people conceive as a limited territory with undefined boundaries, has incorporated diverse immigrant groups who, over time, came together in one place and there formed a society whose internal organization is founded on a conception of the temporal precedence of the constituent groups. In essence and, as will be demonstrated here, in contrast to the rajadom of Sikka, the society of Tana Wai Brama resulted from the movement inward into the domain of origin groups from outside. The origins of Tana Wai Brama through time can be represented graphically as in Figure 1.

The sequence of the arrivals of the ancestors of these clans in Tana Wai Brama, the domain's oda, is elaborated in detail in the origin myths of the domain and the precedence of the members of the clans can be seen clearly today in the political, economic and, especially, ritual relations in the community. All such relations are ordered by the precedence relations of the clans which, all told, make up what James Fox (1995) has aptly described as an 'origin structure'. The phrase is apt because patterns of order in all realms of social life are legitimated by reference to their origins, which provide both corporate groups and individuals with identities and roles in the political and ceremonial order of the community. In particular, the precedence of the clans of the domain is maintained by the unique system of affinal alliance which is at the heart of exchange in the community and in the ordering of those large-scale ritual performances which involve persons from all of the domain's clans. 
Figure 1. The evolution of Tana Wai Brama as a sequence of incorporations of immigrant groups with sukun Ipir Wai Brama as the pu'an ('source', 'central') founder group (time direction clockwise)

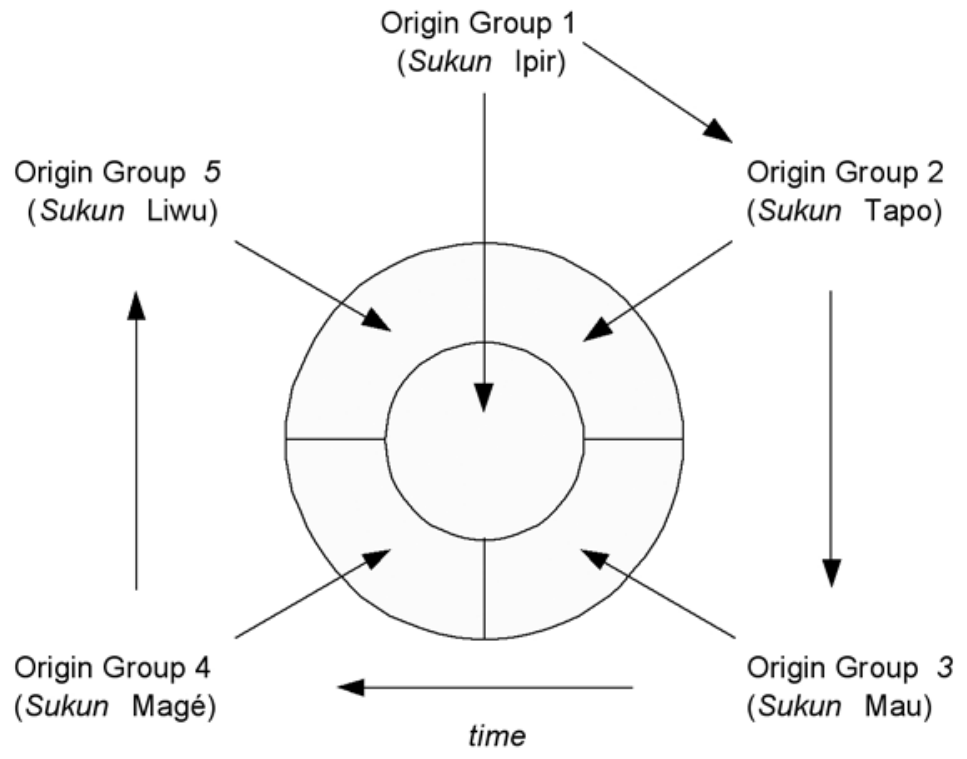

\section{Representations of the Organization of Kerajaan Sikka: The Image of the Broken Plate}

According to Sikka's Hikayat, the most important figures in the foundation of the rajadom were Mo'ang Bata Jawa, Mo'ang Baga Ngang and Sikka's first raja, Mo'ang Don Alésu. Bata Jawa was a law-giver who raised up ritual leaders in local communities throughout Sikka. Baga Ngang, Bata Jawa's son, captured the present-day site of Sikka Natar from the Hokor people. Baga Ngang's son, Don Alésu, is a figure of considerable stature in Sikka. Alésu completed the extension of the rajadom's power to the whole of the district of Sikka and was the first raja of Lepo Geté ('Great House'), the ruling house of the rajas, to use the Portuguese name da Silva, the name used since by all of Don Alésu's descendants and subsequent rajas.

The Hikayat's account of the lives of these three figures includes a striking image representing the relationships of the various negeri ('nations') that the early rajas brought within the polity of the Rajadom of Sikka. I shall refer to that trope as 'the image of the broken plate'.

Porcelain plates found their way to Flores early in the history of trade in East and South-East Asia. Informants in Sikka remember tales of highly valued Chinese ceramics that predated the European presence in eastern Indonesia. Many porcelains from the Ming period (the fourteenth through the seventeenth 
centuries) were painted with cobalt oxide glaze, which yields a distinctive blue on white image. From the sixteenth century, potteries in Delft made fine, porcelain-like ceramics using tin glazes. The Dutch brought their Delftware to the Malayo-Indonesian archipelago, where it was widely dispersed through trade. In Tana Wai Brama, blue and white plates many of later Indonesian manufacture and not authentic Delftware are among the rarest and most highly valued clan heirlooms, which also include ivory tusks and silk Gujarati patola cloths.

The first reference to ceramic plates in the Hikayat is in the early chapter on 'The Life of Mo'ang Bata Jawa', which opens:

In his lifetime, Mo'ang Bata Jawa sailed here and there, obtaining on his journeys large plates which he then brought home to his country [Mekeng Detung]. After returning home, he visited all the inhabitants of his territory, telling them: 'We human beings must have a God, from whom we ask assistance. Thus there must be a place for making offerings. So the plates which I have brought I must divide [BI membagi] among all the nations [negeri] and designate in each a tana pu'ang (Source of the Earth).' So to those who had made villages first he said:

Tiat 'weli a'u nora pigang sisa, To them I confer offering plates, To them I give Dokang 'weli 'au nora luli lokang, Pigang sisa dena sisa mitang, Luli lokang dena lokang bura, round drinking bowls, With the offering plates make black offerings, With the round drinking bowls make white pourings [of palm gin],

Sisa mitang wawa pu'a, Lokang Plates for black offerings down at the source bura réta wutu, Tena neni 'weli [or trunk], Bowls for white pourings up at the ihing, Tena prawi 'weli dolo, tip [or crown of tree], With which to request crops, With which to beg for flowing lontar juice,

Ihing naha tama ronang Dolo Harvests which will fill the granaries, Flows of naha tama téréng... lontar juice which will fill large containers ...

Mo'ang Bata Jawa also distributed the plates to people called $p u^{\prime} u$, 'those of the middle', to the west of Lio and other places. ${ }^{17}$

Later, Bata Jawa's son, Mo'ang Baga Ngang, went around the district pacifying and forming alliances with the leaders of various localities. As the Hikayat relates the tale, the pigang sisa (offering plates) make a second appearance in the narrative of Baga Ngang's career:

After setting things up in the same way as they had at Léku and the other places, [Baga Ngang and his entourage] proceeded to Wodong, to Kodé, to Ropé, and to Hubing, Weke, Wétak, Kangae, Nitung, to Habi Gahar and straight from there to Ili, Moro Piring, where there was a small village which they bypassed, and straight to Pogong Bola, Koker 
Romanduru and the surrounding villages where they did as before, and then he returned to Natar Gahar safely and with gladness because he had accomplished the intention of his heart. ...

Then he made a journey to the west as far as Molé Kéli Samba [Lio] and then onward to Tonggo Keo and to Kasan Toring. Things he gave to a man who became tana pu'ang (laki pu'u [L central man]) there were kept [by the man's descendants] and included a plate called Pigang Sisa that was divided at that time, as well as a mug that was called Luli Lokang. 18

Later in his career, Mo'ang Baga Ngang captured Sikka Natar, the village which would become the seat of the Rajadom of Sikka. Kondi recounts the ruse by which this was accomplished at some length and, in the following section of the Hikayat, entitled 'Mo'ang Baga Moves to Sikka (Old Hokor)', recapitulates the means by which the Sikkanese established their rajadom:

When Mo'ang Baga of Natar Gahar heard that the inhabitants of the village of Hokor had fled in disarray, the people who lived in his village dismantled their houses and set up households in the village of old Hokor, which was renamed Sikka, which means [in SS] 'to chase away'. After they had gotten themselves a good village they built houses that were as solid as palaces. ...

In that period, when we research the nation of Sikka, we find it was before the time of the Portuguese; when they arrived in the year 1559, indeed the people of Sikka were already established. ...

In a year which is not passed down in the history, Mo'ang Baga and Mo'ang Bata Jawa divided a plate as an offering by which they extended their power and came to be respected by all the inhabitants as far as the border of the territory to the east, at Egong and Natakoli Ulung Kowé [Krowé] Jawa; and to the west as far as Mole, Koli, and Samba, all the way to Eko, Leka, and Lambo, which borders Bima (Manggarai)'. ${ }^{19}$

To unravel the significance of the plates mentioned in the Hikayat, it is necessary to examine in some detail the actual language in which the Hikayat refers to them. In the first reference to the plates, in the early chapter on 'The Life of Mo'ang Bata Jawa', the Hikayat quotes Bata Jawa speaking in ritual language which employs the semantically paired phrases pigang sisa // luli lokang (see above).

Pigang is Sikkanese for 'plate', which can be a ceramic, metal or wooden plate. The word sisa is one of the wonderfully polysemous words in Sara Sikka that lend a certain sense of adventure to the translation of Sikkanese and Tana 'Ai ritual language. As a verb, sisa means 'to let go, to drop, to relinquish'. However, in the pleonastic phrase sisa soba, sisa means 'tribute, gift; a 
dedication', as in worship or ritual (Pareira and Lewis 1998). Pigang sisa thus has two meanings:

1. a plate which has been dropped, and thus shattered, and

2. a plate given as (or for giving) tribute or a gift, including such prestations made in dedication of something.

In the passage of ritual language cited by Kondi, pigang sisa is paired with luli lokang. In Sara Sikka and Sara Tana 'Ai, luli is a small bowl made from the fire-hardened shell of a coconut for, among other uses, drinking lontar gin, itself a ritual activity. Luli are referred to frequently in ritual language in both Tana 'Ai and Sikka, as in the phrases from Sikkanese ritual language:

luli wana luli wiri drinking bowls to the right and drinking bowls to the left in reference to the ritual drinking of lontar gin to seal an agreement between two sides to a negotiation (as, for example, wife-givers and wife-takers who have reached agreement on bridewealth in anticipation of a marriage) and:

luli ra'in luli érin drinking bowls uphill (as in the upper course of a river or the upper part of a garden), drinking bowls downhill (as in the lower course of a river or the lower half of a garden).

It is noteworthy that in Tana ' $\mathrm{Ai}$, certain rituals require participating ritualists to exchange luli of lontar gin and, in doing so, to pass one from downhill to uphill and the other from uphill to downhill. Lokang is a 'circle, a hoop, a disk'; it is also a circular race track, that is, a field of competition. The word also denotes the rapid clockwise, then anti-clockwise, rotation of a luli or a round basket containing slices of areca nut before drinking palm gin or chewing areca, a ritual gesture that is common in Tana 'Ai and may have been so in the past in Sikka.

The paired phrases in ritual language, pigang sisa // luli lokang, thus condense a thick web of reference to:

1. the breaking of plates and the sharing or distribution of the pieces;

2. the use of plates in rituals of offering and for the affirmation of alliances, contracts and agreements; and

3. the completeness and wholeness of a circle (which has neither a beginning nor an end) and is, nevertheless, a field of competition.

In normal speech, the precise meaning of utterances which draw upon these words is established by context. But ritual speech is syntactically elided and, in the technical terms of logic, intensionally ambiguous. It is frequently the case that in a phrase of ritual speech that employs a polysemous word, all of that word's meanings are implicated in the meaning of the phrase.

We are now in a position to register some of the echoes and evocations in Mo'ang Bata Jawa's account of the distribution of plates to his allies: 
Tiat weli au mora pigang To them I distribute shattered plates OR plates for sisa offerings OR plates as offerings

Dokang weli au mora luli To them I give circular drinking bowls OR bowls with lokang neither beginnings nor ends

Pigang sisa dena sisa mitang With the shattered OR offering plates make black gifts OR tribute

Luli lokang dena lokang bura With the round drinking bowls make white circles OR circular motions

Sisa mitang wawa pu'a Lokang bura réta wutu Black plate sherds OR offerings down at the source White circular motion OR round bowls up at the tip

To make matters more complicated, plurals are marked morphologically in neither Malay (the language in which Boer and Kondi composed their texts) nor in Sara Sikka. Thus, whether Bata Jawa distributed many whole plates or broke a single plate and distributed the sherds to his allies is also a point of ambiguity in the text of the Hikayat. In either case, the plate, as a symbol, connotes wholeness and completion and so the rajadom was completed by the incorporation of many negeri, to each of which Bata Jawa vouchsafed a plate from a stack of plates $^{20}$ or a sherd from a single, broken plate as a token of each negeri's relationship to the rajadom. ${ }^{21}$ The relationship of the sherds of a broken plate or each in a stack of plates to the other and to the basket in which they are transported is that of the parts to a whole, which is a relationship of complementarity rather than hierarchy. It is this image that Sikka's Hikayat iterates and reiterates in representing the relationship of Sikka and the rajas to the negeri of which the rajadom was composed. Thus, at the level of ideology, as encoded in speech and in a literary version of Sikka's history written by teachers who became officials in the raja's government, the relationship between raja and negeri was one of complementarity rather than hierarchy, as between ruler and ruled or superior and subaltern.

This image does not necessarily represent the actual political and social arrangements in the rajadom but, rather, a conception and representation of the relationship that is distinctly non-hierarchical. Indeed, the reality beyond the mythic history of the rajadom was somewhat different and certainly more complex than the depiction of Sikkanese society as sherds reforming themselves as a whole.

\section{Precedence Relations in Sikka Natar and Hierarchy in the Foundation and Evolution of the Rajadom of Sikka}

As told in the Hikayat, the history of Sikka unfolded in two principal stages. The first was the creation of Sikka Natar, a single village, and the second was the creation of the rajadom with Sikka Natar at its political centre. Sikka Natar grew by a process very similar to that which generated Tana Wai Brama. In both 
Tana Wai Brama and Sikka Natar, a succession of groups of immigrants were incorporated into the community. In the second stage of Sikka Natar's history, in which it became the seat of a petty state, the community expanded its territory to subsume the whole of central Sikka by incorporating other communities into a single polity. The incorporation of newcomers in Wai Brama produced a society ordered by the precedence of its constituent groups while in Sikka, territorial expansion, a development that did not occur in Tana Wai Brama, produced a polity of allied groups among whom precedence was immanent and a differentiation of people into social classes of rulers and ruled ordered by hierarchy.

Fox (this volume) has noted that:

Precedence refers both to forms of discourse and of practice. In considering precedence as an analytical category, it is appropriate to distinguish aspects of discourse and practice. However, in social analysis based on the use of precedence, it is the fusion of these aspects that gives credibility to the concept.

The myth of the foundation of the Sikkanese rajadom, which is part of the expressive, representational and discursive repertoire of the Ata Sikka, includes an account of the evolution of Sikka Natar, which grew over time by the addition of groups of immigrants who, the Hikayat relates, originated from 36 different places. While neither Boer's and Kondi's version of the Sikkanese myth of origin nor those oral versions I have recorded in Sikka Natar emphasizes a precedence ordering of these groups, precedence can be detected in the relationships of their members, principally through the complex network of contemporary affinal alliance relationships in which their contemporary descendants are enmeshed. Thus, Sikka Natar can be seen as a precedence-based social order in which manifestations of precedence in social practice have been partially masked by the institutions of the rajadom while remaining a strong theme in myth and affinal exchange.

Whereas contemporary ethnographic data provide evidence for viewing Sikka Natar as a precedence-based social order, the history of the Rajadom of Sikka and the role of Sikka Natar in the evolution of the rajadom have eclipsed this aspect of representations of society. Instead, both the Hikayat and the testimony of my informants in Sikka emphasize a process of state formation that resulted in a polity and social order articulated by a hierarchy of social classes.

The people of Sikka Natar were distributed among four social classes: the class with the smallest number of members was Lepo Geté, the house of the rajas and their immediate kin. Clustered around the raja and Lepo Geté were a number of noble houses, from which came the mo'ang pulu (SS 'ten lords') and the kapitang (SS, from P, 'captain[s]'), such as Boer and Kondi, who were district officers in 
the raja's government. Ata riwung (SS 'thousands') or ngasung riwung (SS 'hundreds and thousands') were rakyat (BI 'society'), the free commoners of Sikka Natar and the rajadom. Maha (SS) were indentured retainers attached to the households of the nobles until the early post-war years. Many Sikkanese themselves have described their society as 'feudal', a description originating from the early missionaries of the Church. ${ }^{22}$ The Hikayat affirms this view, but does not dwell on the social classes of Sikka Natar and the rajadom.

The royal house, according to genealogies compiled by Boer, traced its origin to Raé Raja and Rubang Sina, the captain of the ship carrying the second group of immigrants to land on Sikka's southern shore. ${ }^{23}$ Their son, Mo'ang Sugi, married Du'a Sikka, who was penduduk asli (BI 'indigenous inhabitant'). The descendants of the union of autochthon and newcomer became the rulers of Sikka. The origins of the noble houses of Sikka, the mo'ang pulu, or 'ten lords', are not described in the Hikayat, nor have I much information on their origins in my field notes on Sikka. How some among the immigrants who came to Sikka came to be mo'ang pulu while others did not is another puzzle in the history of Sikka.

The Hikayat mentions the mo'ang pulu only three times. Firstly, in the account of 'The Life of Mo'ang Bako I Alias Mbako Kikir Hiwa' (Bako the First, known as 'Nine Fingered Bako'), the tenth raja of Sikka:

So this was the era of the Portuguese government here in Flores, taxes were collected by their own king and they also organized their own government as is clear in the book of laws of the kingdom, that is mo'ang pulu alias the heads of every tribe in Sikka and every captain with his own tribe helped the king in his government and especially at the time they went down into the valley (times of war). ${ }^{24}$

Second is a brief mention of the death of the subaltern raja of Nita in 1891:

On the 25th of November 1891 the corpse of the King of Nita was buried. Those who were present were only the King of Sikka with Commandant Joh Iking da Cunha from Maumere, Mo'ang Pulu from Sikka/Maumere and the chiefs [kepala-kepala BI heads] and the people from Nita. ${ }^{25}$

And, thirdly, in an account of a rebellion put down by the Sikkanese raja:

The chiefs of Sikka (Mo'ang Pulu with five captains) intended to try and obtain compensation or reimbursement for their losses in the war or pay blood money [SS: heka] for all the deaths. ${ }^{26}$

Details of Sikka's social hierarchy remain, on the evidence, somewhat obscure, but it appears to have been founded on a conception of the proximity of a person or social group to the raja calculated in terms of the raja's origins and the origins of a related group. The raja was at the 'centre' of the rajadom while the nobles, 
commoners and retainers were increasingly 'distant' from the raja. The continuum formed by a periphery in relation to a centre, on which relations of precedence can be calculated, is a common dualistic metaphor in Tana Wai Brama. In Sikka Natar and the rajadom, the continuum of precedence was translated into a rank-ordering of social classes by the imposition of a schema of discrete categories onto the continuum (Figure 2).

\section{Figure 2. Ranking of social classes in Sikka Natar and Kerajaan Sikka}

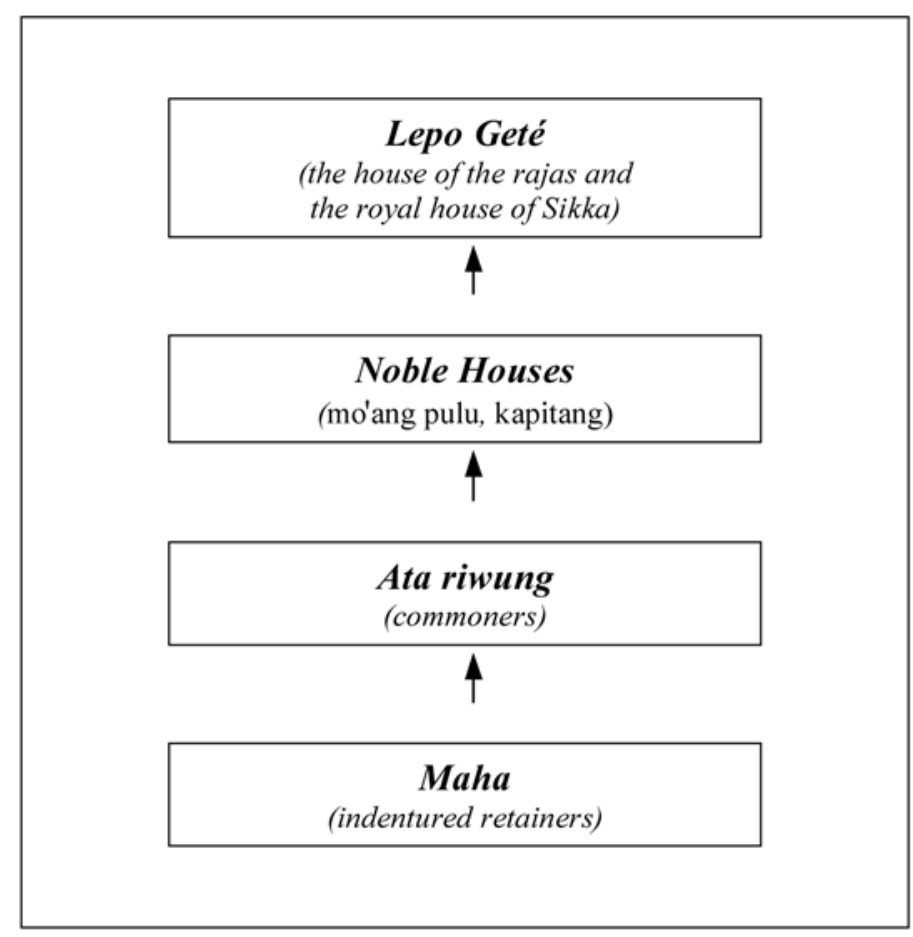

While reflecting an ideology of precedence, the Hikayat pays less attention to the internal organization of Sikka Natar and more to the hierarchical political structure of the rajadom. In short, the Hikayat is a charter of this hierarchy. Thus, the groups which make up the village community are linked by relationships founded in the precedence of their arrival in Sikka Natar, while the kerajaan, the confederation of negeri over which the rajas of Sikka ruled, is represented in the Hikayat as hierarchical in its structure. Even so, underlying the political organization of the rajadom as depicted in the Hikayat is the precedence of Don Alésu, as secular leader, over Augustinyu da Gama, the religious leader. In this respect, precedence underlies hierarchy in the evolution of the rajadom (Lewis 1996a). ${ }^{27}$ 
Four principal elements intertwined in the creation of the Rajadom of Sikka: an indigenous house which aspired to rule, the numerous independent and local negeri into which the Sikkanese-speaking peoples of Flores were divided, the introduction of Christianity, and the presence of Portuguese and, later, Dutch foreigners. The creation of the rajadom from these elements is the subject of much of the Hikayat. In synthesizing the principal elements of the rajadom into a narrative chronicle, Boer and Kondi construct a history of the rajadom in which an ordered sequence of incorporations of disparate communities into a polity is a major theme which is still of considerable force in the affairs of Sikka today. The persons who brought about these incorporations were related to one another in time and Kondi cites their genealogical relationships to legitimate their claims to authority and power in the rajadom thus created.

For almost a century from the second half of the 1800s, Sikka was a semi-independent kerajaan, one of a number of petty polities in eastern Indonesia recognized by the Dutch under the policy of zelfbestuur (D self-rule). The rajadom's semi-independence continued after Japanese troops entered Maumere in 1942, with the Japanese military government of the island levying taxes and corvée labour through the authority of the raja of Sikka, who was then Raja Don Thomas Ximenes da Silva. After the war, the rajas of Flores took the island into the briefly-lived independent Republic of Eastern Indonesia and, as head of the Dewan Raja-Raja Flores (the Council of the rajas of Flores), Raja Thomas played a central role in guiding both Sikka and the island through this fraught period in eastern Indonesia's history. Don Thomas died in Ende in 1954 and, although Don Sentis [Centis] da Silva, the raja muda (BI prince), assumed the title of raja, in all practical respects, the rajadom ended with Don Thomas's death.

As recounted in the Hikayat, Sikka expanded through a sequence of alliances contracted with independent negeri to the north, east and west of Sikka Natar. The practice of the rajas after Baga Ngang was as follows: the raja of Sikka contracted an alliance with a local leader by presenting to him items of ceremonial wealth, principally elephant tusks, but also gai (M tongkat), a staff of office. In return, the local leader pledged allegiance to the raja and accepted the raja's authority in matters outside of the immediate local concerns of the negeri. Later, with the rajas' appointments of kapitang as district heads, the rajadom came to exercise power within the negeri as well. The items of ceremonial wealth by which the alliance was secured were, with the exception of the gai, those used within Sikka Natar as bridewealth.

In bridewealth transactions, each party in a marriage makes prestations to the other. The goods exchanged are, however, of different kinds. Wife-takers, who are mé pu ('children and sisters' children'), give ling wéling, 'bridewealth', 28 to wife-givers. These gifts consist of ivory tusks, gold coins, horses and cash, goods classified as masculine. In return, wife-givers, who are ina ama (SS mothers 
and fathers), give to their wife-takers a counter-prestation called 'utang labu wawi paré (SS [women's] cloths, blouses, pigs, rice), goods classified as feminine. While the Ata Sikka say that these reciprocal gifts are of equal value and balance each other, the prestations are laden with asymmetries of value: as parents are superior to children, so are wife-givers superior to wife-takers, and as masculine goods are conceived to be superior to feminine goods, thereby serving as proper tokens of exchange for the capability of providing the wife-taker's group with new life, so are wife-givers who receive masculine goods superior to wife-takers, who receive feminine goods.

The asymmetry of the wife-giver and wife-taker relationship rests, however, not on these relatively explicit evaluations of gifts, but on the unstated valuations of the persons exchanged. In strictly formal terms, in a Sikkanese marriage, an alien woman enters the house of her husband which, by the children she bears, she reproduces. Her own group loses her reproductive capacity and must seek women from yet other groups to perpetuate itself, a risky business in the Sikkanese conception.

The debt incurred by wife-takers when they receive the gift in marriage of a woman and her reproductive capacity is a debt that is never and cannot be fully discharged. For this reason, and with respect to 'the flow of life' between affinal allies, wife-givers are innately superior to wife-takers. The reason for this asymmetry of value is the greater power of women over men as reproducers of houses, regardless of the value (and valuation) of the prestations that serve as tokens of the exchange between houses and their alliance (and this among a well-educated people who have, nevertheless, not yet read Lévi-Strauss).

Thus, beneath the symmetry of gift-exchange (you give us ivory; we give you cloth), affinal alliance in Sikka is founded on a profound asymmetry of value in which the receiver of symbols of greater value (bride-wealth) is superior to the giver of those symbols (Figure 3). Bridewealth (ling wéling), which is classified as masculine, is of greater value than 'utang labu wawi paré, the counter-prestation which is classified as feminine, precisely because women are more highly valued than men. The house that receives a woman thus also receives prestations of less ritual value than those which they give.

In the realm of the political alliances by which the Sikkanese created the Rajadom of Sikka, the value that was transacted was not the life-giving power of women, but political allegiance, authority, and power. Thus, while giving ceremonial wealth of a kind which, in the affinal alliance system, would be classified as masculine (thus implying that the recipients were the superior party), the raja received political allegiance and, in terms of the polity relationships, acquired political and hierarchical superiority over the negeri. Given that the unstated value transacted was power and authority, the formation of the political alliances upon which the rajadom was founded involved the same 
them 'wife-givers' to the raja by virtue of having received the superior symbol, the raja's bridewealth. But this was not the case from the rajas' point of view. The rajas had shifted the rules: what was transacted was not allegiance, per se, but power. The idiom of the transaction was that of bridewealth and the gift of bridewealth goods implied non-hierarchical, asymmetric, and cyclical exchange. But the fact was the establishment of a status system whose classes were related hierarchically rather than the simple elaboration of a system founded in the complementary asymmetries and precedence relations of affinal alliance.

It can thus be seen that the Sikkanese constructed their rajadom by drawing on principles of value and echange embedded in their culture and in the realm of domestic and affinal alliance within their home village, Sikka Natar, but with a peculiar play on the logic of exchange. The politics of exchange they invented were not merely a matter of the trappings of power and the ceremonial prestige which accrues to a ruler, but had material consequences. Among others, as the bearers of authority throughout their realm, the rajas recruited troops to aid the Portuguese in Timor and, later, reached accords with the Dutch whereby they taxed the people of their domain.

The same pattern can be seen in the mythic histories of Tana Wai Brama, in which the people of clan Ipir Wai Brama, by virtue of being the first to come to the domain, became the tana pu'an, the source of the domain. Each subsequent immigrant received land for gardens and positions in the ceremonial system of the domain, in return for which they recognized the authority of the source of the domain over the land and in relations with external powers such as (in later years), the Rajadom of Sikka. The difference between Tana Wai Brama and the Rajadom of Sikka was that the tana pu'an of Tana Wai Brama never acquired political power in the manner of the rajas but retained authority limited to the realm of ritual.

It is perhaps worth noting that the alliances between Lepo Gete and the negeri did not involve marriages of people of the negeri and the house of the Sikkanese rajas. While such marriages occurred, they appear to have played little role in the calculations of political relations of superordination and subordination. However, it is further worth noting that marriages of people of the Sikkanese royal house did play a role in relationships with other rajadoms on Flores. Thus, for example, in the 1920s a daughter of the raja of Sikka married a son of the raja of Larantuka. The Sikkanese remember this union well, both for its political implications (it finally put to rest the long-standing enmity between the rajas of Sikka and Larantuka) and because by this marriage the raja of Sikka became wife-giver, and thus ritually superior (at least, from the point of view of the Sikkanese) to the ruling house of Larantuka.

In the Hikayat there are many mentions of the exchange of ceremonial wealth for political allegiance. In 'The Second Era' of Sikka's history, which was that 
of the rule of Don Alésu, the Hikayat reiterates the means by which the rulers of Sikka secured their authority over the rajadom. The following excerpt illustrates the general principle:

Don Alésu spoke to the heads of the tribes of Sikka saying: how well it would be if we were to go and visit the countryside and villages since it has been a long time since I visited our people; and we must take the ivory tusks which I brought from Malacca and place them in the largest and busiest territories (negeri) so that when people see the tusks they will think of me. His [Alésu's] intention was that if there ever was a rebel, he would see the tusk which is a sign of my [Alésu's] li'ar dira, rang ngang, my sharp voice and my powerful manner, a sign of the raja of Sikka. And those who guard and keep the tusks will be entitled Mo'ang Mangung, which means the masts of the prau; this phrase means further standing erect or upright, at one's full length like a tree. His aim was to show the uprightness of his creation and that the raja of Sikka is not submissive to anyone else in the rajadom. Said Don Alésu:

Waké néi ba'a mangung, After you have erected the mast of the great ship, Mangung lepe lau prebeng, The mast that shelters the door sill, And after raising 'Ore né'i nora lajar, Lajar the sail, With the sail slapping the mast, tongka wawa dang,

Odo ganu serdadu, Gareng Then I give orders as to troops, I lead as you lead a ganu marsélu (manyelu), corps of soldiers, So when speaking, do not Kiring li'ar lopa leder, contradict others, And when counting, do not Gata wang lopa gawang, exaggerate,

Dena niang lopa biko 'liong, So that the earth does not bob up and down like an Tana lopa kiling kolok, Dadi mangung wau 'wisung, Lajar gong wangang,

Tali lera léma waté. And the sail's sheet raises the liver [that is, heart].

N.B. It was usual to give a 'mast' (mangung), that is, a tusk at least a fathom in length, to the large villages. The 'sail' (lajar) was a doko, or a crescent shaped piece of gold, given to small villages. Tali lera (the sail's sheet) was a length of chain given to many smaller hamlets. ${ }^{29}$

The text then contrasts Don Alésu's method of alliance formation with that of the previous two rajas:

In the time of Mo'ang Bata Jawa and Mo'ang Baga Ngang they divided large plates to be offered to the gods, that is: pigang sisa. ${ }^{30}$

Thus, perhaps significantly, Bata Jawa and Baga Ngang, the two pre-Catholic proto-rajas, distributed plates to those with whom they contracted alliances, 
whereas Alésu, the first of the Catholic rajas, distributed to his subalterns ivory tusks and gold, which he had acquired in Malacca and brought back to Sikka.

The narrative continues:

Thus Don Alésu returned from giving the bala mangung ('ivory mast'), saying:

A'u pangkor Sikka paing lado, Ata bi'ang pu'ang humang, Uring lau bénu wuli, Wa'ang réta paing lado. Waké né'i mangung, Sorong néi pangkor Sikka, whose hats are pu Pangkor Sikka paing lado, Ata bi'ang pu'ang humang.
I am the hero of Sikka whose hat bears a plume, The person who is the source of war, Around my neck I wear beads and shells, My head wears a plumed hat, I have installed the central mast, And promoted soldiers of Sikka to office, Those heroes of Sikka whose hats are plumed, The men who excel in war.

The praise for the raja when he grants the 'ivory mast':

Ina lau krus pu'ang, Diat The mother who stands below the cross, Has given beli nora pu'ang, Ama lau the strongest foundation, The father who stands gereja wang, Dokang beli before the door of the church, Has bestowed nora kating, authority,

Baké ba'a nora mangung, And has raised up the ship's mast, So the ship will Bikong 'lo'a lopa 'liong. not pitch and roll, And has hoisted the sail, So it Oré beli ba'a nora lajar, does not droop and flutter, Kiling ba'a 'lo'a lopa kolok,

Mangung lau laru walu, Eight masts below, Seven sails above. Lajar lusi réta wata pitu.

The reply of the people who receive the 'ivory mast':

Belirang Amat, 'Ulit gung Like the volcano Belirang Amat, Your skin is thick mako lékong, Naha amat and old but not scorched by the sulphur, Only you geru mela. can swallow it.

In this way Don Alésu da Silva visited all of the territories in the western part of Flores, including Keo, Torung, Lambo, Toto, Mbei and Kota Jogo, and returned by sea along the north coast landing at Kero Kelisi and then straight on to Bebeng (Wuring). At each landing he delegated a deputy to summon the inhabitants or went ashore and visited them himself. ${ }^{31}$

The elephant tusks which the rulers of Sikka distributed to the leaders of local communities were called bala mangung (SS ivory mast). Over time, the bala mangung and the villages in which the rajas placed them came to mark the territorial limits of the authority of the raja of Sikka. Kondi cites the raja of 
Sikka's dispute with the raja of Larantuka over rights to tax the people of Téru to the east of Maumere and comments:

the former rajas from the time of Raja Don Alésu had put the ivory in Téru because, wherever the ivories of Sikka were, there also was the authority of the raja. Usually the rajas of Sikka placed ivory called bala mangung in a large negeri. The person who kept it was titled Mo'ang Mangung, and the negeri and its surrounding area were allies with Sikka (there was also ivory which was kept by tana pu'ang, which were called bala tana pu'ang). ${ }^{32}$

Furthermore, according to the Hikayat:

The goods [the elephant tusks and other gifts from the raja of Sikka] were kept in a place (a district, a village) as a sign that they were allies with or federated with Sikka. So [in the case of Téru and the dispute between the rajas of Sikka and Larantuka over taxation], it was better to call the people from Téru (Koja Mota) who kept the ivory, so that they could explain in more detail from where the ivory came. ${ }^{33}$

These gifts from the raja to local headmen established the sovereignty of the raja, but the expectation was that the local people of the negeri kept the 'histories' of the gifts and Kondi continues:

Obviously their ancestors would have told them the story about it over and over. $^{34}$

\section{Conclusion: Precedence and Hierarchy in the Sikkanese Culture Complex}

Despite similarities between Sikka and Tana Wai Brama, among the differences between them is this. As the home village of the rajadom, Sikka Natar began as a confederation of immigrant groups, but incorporated new groups by territorial expansion in its later history. Sikka's development can thus be conceived as extensional. In contrast, the development of the society of Tana Wai Brama can be described as intentional. Wai Brama never expanded its territory, but incorporated new groups by assimilation as they arrived in the domain.

To the extent that this is so, Figure 1 and Map 1 provide, in graphic form, the clues we need to understand the most fundamental difference between Sikka and Tana Wai Brama. The mythic histories of Tana Wai Brama tell the story of how a limited number of origin groups came from outside and moved inward into the domain. Since its foundation, people from clans other than the five core clans of Tana Wai Brama have taken up residence in the domain, but not in large numbers and not in sufficient numbers to require a change in the representation of society as made up of five groups. In contrast, Sikka expanded territorially, incorporating as it expanded communities of diverse identities. In principle 
there might have been no end of that expansion (in practice Kerajaan Sikka ended at the frontiers where its territory bordered that of neighbouring rajadoms or was limited by the Dutch). It may be that an overlay of hierarchical order is a necessary condition of an extensional polity, but, whether this is generally true or not, it was the solution to the problem of government devised by the rajas of Sikka.

\section{Map 1. Schematic representation of the expansion of the Sikkanese polity}

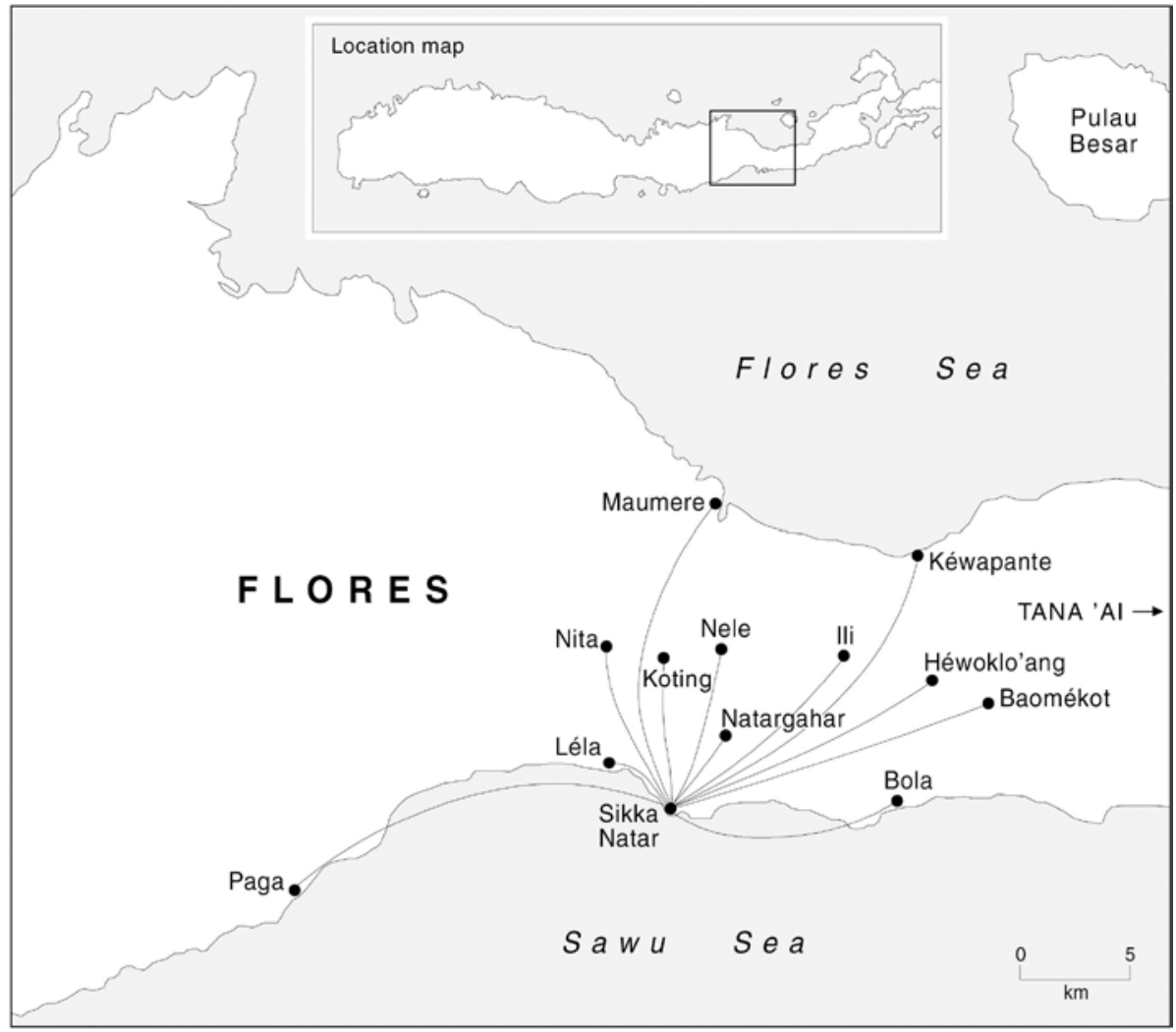

But there is more to be learned from the comparison of precedence in Tana Wai Brama and Sikka than the ways in which, in each case, it accords with a particular and distinctive modulation of territorial space. It may be that precedence-based social systems conceive and structure time and history in ways different from hierarchy-based social systems.

In both Tana Wai Brama and Sikka, contemporary states of affairs are constantly discussed, explained and manipulated in terms of the past. And, in this respect, Tana Wai Brama and Sikka are remarkably similar despite apparent differences. In addition, the pasts of both societies include beginnings with the coming together of immigrants over time. Both societies recognize a group of people who were first immigrants, and who were thus founder groups, but 
neither society recognizes any group as descendants solely of autochthonous people. This means that, in their histories as they are conceived by contemporary people and represented (whether orally in the narration of myth or in writing), the descendants of the founding ancestors, those who today claim social, ceremonial or political pre-eminence, must make their claims not in terms of some special relationship to place, location, land or territory, but in terms of temporal precedence which, to a degree, is shared by the descendants of the founding ancestors of all the constituent groups of society. Claims to precedence (and hence pre-eminence with respect to some aspect of social life) are claims to position on a scale of relative positions, each of which is gauged by reference to the single value of temporal priority.

Precedence thus differs from hierarchy which, as Dumont (1980:241-243) has argued, is founded in a logic whereby a classificatory unity encompasses categorical difference. The peoples of Sikka conceive of the constituent groups of their societies neither as opposed to one another nor as one encompassing another, but in terms of the accretion of elements in time, each related to the others as complementary parts of wholes. In Sikka, such tropes as the broken plate are transformations of the complementary relationships that obtain between, for example, wife-givers and wife-takers and between feminine and masculine categories in a system of dual classification that permeates Sikkanese thought. The same is true of Tana Wai Brama, whose people emphasize in both discourse and action the complementarity of the clans that constitute the domain, the houses that constitute a clan and (as in Sikka) the wholes that result from the bringing together of male and female (Lewis 1996c).

Nevertheless, Sikka contrasts with Tana Wai Brama in a number of respects, all of which, I would argue, spring from its peculiar history as a polity and a petty state. Firstly, the incorporation of alien negeri into the rajadom had as a practical result the need to maintain a distinction between ruler and ruled. The raja was the ruler; the people of the communities of the larger region of Sikka were the ruled. But even this apparent opposition was mitigated by the mo'ang pulu, the 'ten lords', who were drawn from the nobility of Sikka Natar (that is, from the oldest houses of Sikka) but who lived in the kapitanschappen, the administrative districts into which the rajadom came to be divided during the period of Dutch rule after the 1860s. Thus, the apparent opposition between ruler and ruled was in fact a hierarchy of four classes which cross-cut local identities: the people of the royal house, the people of the Sikkanese nobility, the free commoners and indentured retainers. Indeed, while all were under the political authority of the ratu, each negeri had its own headman, its own tana pu'ang (source of the earth) and its own ngasung riwung (SS 'hundreds and thousands', that is, 'common people', 'society'). 
In Tana Wai Brama the asymmetry of affinal alliance, the precedence of complementary origin groups in the composition of society and the dynamics of social and ceremonial exchange produce a fluid social system in which, through generations, the descendants of ancestors change status as the dynamics of the social system necessarily reallocate them among clans and among houses within clans (see Lewis 1988a). In Sikka what once may have been an analogous system acquired the added dimension of social statuses which were (and to a degree are still today) represented as ascribed and inflexible. ${ }^{35}$

Tana Wai Brama provides us with an excellent example of a society in which we find precedence in its clearest manifestation. Sikka provides us with another, perhaps more profound, example of a society which at once manifests both precedence and hierarchy. This tells us that the two principles of order, at least as they are found in Florenese societies, are by no means incompatible and suggests that they can be transforms of one another.

In precedence, one sequence of events in the past provides a model for - or the proper interpretation and order of - events in the future, but in restricted realms. Precedence thus involves a reduction in scale from the 'real time' of history to bounded 'ritual time' and 'social time'. This allows (1) the preservation of the past as a template for future action and (2) the free occurrence of future random events, the order of which defines future precedence relations. Precedence as process converts chaos into future order and acts as a governor, a kind of feedback loop, which promotes a degree of homeostasis in the social system. By precedence, some in the community become guardians of hadat ('traditions') while others are free to challenge the old ways; some may become rulers and others subjects of rule without losing all freedom of action.

Thus, precedence is about both structure and action. But more than a structure, precedence is a temporal template for how things should go (and how things that go should be interpreted) in the future. The result is an observable similarity, a common pattern between occurrences of delimited events. Precedence leads to the ritualization of events; an original sequence of random events becomes orderly by the acquisition of meaningful sequentiality. In other words, in precedence, the future and the past are in a relationship of complementarity. Hierarchy, in the Sikkanese case, accords with a history that is extensional and open-ended and, thus, progressive.

Tana Wai Brama and the Rajadom of Sikka are cases in which we find both processes of social differentiation and integration. In both, people of disparate origins entered into confederations and became integrated, their unification giving rise to societies. Integration and unification nevertheless allowed the groups to preserve their original identities in terms of precedence: we are not you because our ancestors arrived after (or before) yours. These cases from a single district of Flores thus also illustrate how a single and formally simple 
principle of order and organization can, through time and the contingencies of history, produce social differentiation, in one instance, a proliferation of houses within clans and, in the other, a system of social classification that ordered authority and the exercise of power in an expanding polity.

This essay owes much to Professor J.D.M. Platenkamp of the Westfälische Wilhelms-Universität Münster who, while convincing me to share a bottle of Scotch whisky in Leiden one night in late 1993 or early 1994, could not convince me that what I meant by precedence was logically a transform of what Dumont meant by hierarchy. For my part, I do not remember whether I convinced him of my reasons for thinking that eastern Indonesian societies are fundamentally different from Indian societies, for by the time the argument progressed to that point, the bottle was just about empty. My thanks to Professor Richard K. Reed and to Trinity University, San Antonio, Texas, which, in 2008, provided me with a congenial academic home in which to revise the essay.

\section{References}

Butterworth, D.J.

2008 Lessons of the ancestors: ritual, education, and the ecology of mind in an Indonesian community. Unpublished PhD thesis. Melbourne: Department of Anthropology, The University of Melbourne.

Dam, H. ten

1950 Nita dan sekitarnya. Bogor: Balai Perguruan Tinggi R.I., Fakultet Pertanian. Dumont, Louis

1980 Homo hierarchicus: an essay on the caste system. Revised edition. Chicago: The University of Chicago Press.

Fox, James J.

1995 Origin structures and systems of precedence in the comparative study of Austronesian societies. In P.J.K. Li, Cheng-hwa Tsang, Ying-kuei Huang, Dah-an Ho and Chiu-yu Tseng (eds), Austronesian studies relating to Taiwan, pp.27-57. Taipei: Symposium Series of the Institute of History \& Philology: Academia Sinica 3.

Lewis, E.D.

1988a People of the source: the social and ceremonial order of Tana Wai Brama on Flores. Verhandelingen van het Koninklijk Instituut voor Taal-, Landen Volkenkunde 135. Dordrecht, Holland/Providence, USA: Foris Publications. 
1988b A quest for the source. The ontogenesis of a creation myth of the Ata Tana 'Ai. In James J. Fox (ed.), To speak in pairs: essays on the ritual languages of eastern Indonesia (Cambridge Studies in Oral and Literate Culture, No. 15), pp.246-281. Cambridge: Cambridge University Press.

1989 Idioms of kinship in the cosmological thought of the Ata Tana 'Ai. Mankind 19(3):170-180.

1996a Origin structures and precedence in the social orders of Tana 'Ai and Sikka. In James J. Fox and Clifford Sather (eds), Origins, ancestry and alliance: explorations in Austronesian ethnography, pp.154-174. Canberra: Department of Anthropology, Research School of Pacific and Asian Studies, The Australian National University. Comparative Austronesian Series, ANU E Press: http://epress.anu.edu.au/.

1996b Myth, history and precedence in the chronicles of the Rajadom of Sikka. Paper presented to the conference on 'Hierarchization in the Austronesian world: processes of social differentiation', International Institute of Asian Studies, Leiden, The Netherlands (April 1996).

1996c The paradox of difference: essays on kinship and gender relations in Tana Wai Brama. Unpublished manuscript.

1998a The tyranny of the text: oral tradition and the power of writing in Sikka and Tana 'Ai, Flores. Bijdragen tot de Taal-, Land-en Volkenkunde 154(3):457-477.

1998b Don Alésu's quest: the mythohistorical foundation of the Rajadom of Sikka. History and Anthropology 11(1):39-74.

1999 The encyclopædic impulse: accounts of the origin of the Rajadom of Sikka by two Sikkanese authors. Bijdragen tot de Taal-, Land-en Volkenkunde 155(3):543-578.

forthcoming. The stranger-kings of Sikka. Leiden: KITLV Press.

Lewis, E.D., Timothy Asch and Patsy Asch

1993 A celebration of origins. 16mm film. Watertown, Massachusetts: Documentary Educational Resource, Inc.

Lewis, E.D. and Oscar Pareira Mandalangi

2008 Hikayat Kerajaan Sikka. Maumere, Flores: Penerbit Ledalero.

Metzner, J.K

1982 Agriculture and population pressure in Sikka, Isle of Flores: a contribution to the study of the stability of agricultural systems in the wet and dry tropics. Development Studies Centre Monograph No. 28. Canberra, Australia, and Miami, Florida, USA: The Australian National University. 


\section{Pareira, M. Mandalangi and E. Douglas Lewis}

\section{Kamus sara Sikka bahasa Indonesia. Ende, Flores, Indonesia: Penerbit Nusa Indah.}

\section{ENDNOTES}

1 See Butterworth (2008) on the distinctiveness of the Krowé communities of central Sikka.

2 Lewis and Mandalangi (2008); see also Lewis (1998a, 1998b, 1999, and forthcoming).

3 See Lewis (1999) and Lewis (forthcoming, Chapter III).

4 See Lewis (1998a, 1998b and forthcoming) for accounts of the provenance of Boer's and Kondi's manuscripts and how they came to my attention. An edition of Boer's and Kondi's longest manuscripts that integrates the authors' works into a single narrative is now in press under the title Hikayat Kerajaan Sikka (Lewis and Mandalangi 2008). Lewis (forthcoming) includes an English translation of an abridgment of the Hikayat with ethnographic notes and analyses of the text.

5 BI for Bahasa Indonesia, M for Malay, SS for Sara Sikka, D for Dutch, P for Portuguese, L for Lio.

6 The phrase Hindia belakang is a translation into Malay of the Dutch geographical term achter Indie ('beyond India'), which designates East and South-East Asia.

7 Lewis forthcoming, Chapter X, 'Don Alésu's Journey to Malacca'.

8 Indeed, Boer's and Kondi's narratives of Don Alésu and Augustinyu da Gama, while much more detailed, are essentially the same as those which I recorded as highly elided oral renditions in Sikka Natar in the late 1970s.

9 The last controleur of Maumere, Mr W. Coté, immigrated to Australia after the war and settled in Melbourne.

10 I will be most grateful to anyone who can tell me that the name Worilla appears in a history of Malacca, western Indonesia, or Malaysia. The name appears neither in the Malay Annals nor in other historiographic sources I have examined.

11 See Lewis (1996a:162) for a chart showing the genealogical relationships of the 18 rajas of Sikka, but note a typographical error in that work: whereas the name Baga Ngang appears twice in the published version (generations 11 through 13), Bata Jawa's son was Mo'ang Igor and Igor's son was Baga Ngang. See also Lewis (forthcoming) Chapter II, 'Structure and Themes of the Hikayat Kerajaan Sikka', for variants of the genealogy of the da Silva dynasty.

12 'The First Period' thus accounts for the creation of diarchies in the local negeri, in which authority was divided between a ritual leader and a secular leader; see Lewis (forthcoming), Chapter IV, 'Diarchy in the Eastern Lesser Sunda Islands and Sikka', for a critique of the concept of diarchy in the ethnology of the eastern Lesser Sunda Islands.

13 Lewis (forthcoming), Chapter VII, 'The Autochthons'; Lewis and Mandalangi (2008:7-10), Bab I, 1.1 'Orang Asli'.

14 The exact location of Mekeng Detung, which is important in the mythic histories of both Sikka and Tana Wai Brama, is something of a puzzle. Both the Hikayat and my Sikkanese informants place Mekeng Detung near Ili Bekor, which is one of a series of peaks in a range of mountains arrayed along the east-west spine of the island in central Sikka south-east of Maumere and some three kilometres from the south coast of the island and nine kilometres from the north coast. This range of peaks includes (from west to east): Ili Néwa (752 m.), Ili Gai (909 m.), Ili Bekor, Ili Tolawair (944 m.), and Ili Jele (956 m.) Of these mountains, Bekor is the most frequently mentioned in the Hikayat and is closely associated with Mekeng Detung. Metzner identifies the contemporary villages of Natarloar and Tadat, which are very near one another and are located about four kilometres to the north-east of Ili Bekor, as Mekeng Detung (Metzner 1982:282). However, four kilometres is a considerable distance in a region only 12 kilometres across from north to south. I have no direct evidence which confirms Tadat and Natarloar as Mekeng Detung, either from contemporary Ata Sikka or from the Hikayat, which mentions neither place. Boer's notes refer to Mekeng Detung both as a specific place and as a region encompassing a number of villages in central Sikka. It is perhaps significant that, in Sara Sikka, the name of Ili Bekor means 'to arise, to rise, to emerge, to come out, to well up, to come out of'. In the mythic histories of Tana Wai Brama, the founders of the domain are said to have bubuk bekor (SS), to have 'bubbled up (as water at a spring) and emerged (from the earth)' at Mekeng Detung, the same place cited in the Hikayat as that where the Ata Sikka first settled. 


\section{Precedence}

15 In some Sikkanese texts, Woloarung appears as Wolo Laru or Wolo Larung.

16 See Lewis (1988a, 1996a, 1996b). Lewis, Asch and Asch (1993) depicts the ways in which precedence informs the performance of ritual in Tana Wai Brama.

17 Lewis (forthcoming), Chapter VIII, 'The Life of Mo'ang Bata Jawa'. The word pu'u (SS) means 'centre', 'middle', 'in the middle' and, in folk etymology, is linked to the word pu'a, 'trunk (of a tree)'.

18 Lewis (forthcoming), Chapter IX, 'The Life of Mo'ang Baga Ngang'.

19 Lewis (forthcoming), Chapter XIX, 'The Life of Mo'ang Baga Ngang'. Ili Egong, also known as Ili Mapi, is an active volcano and, at 1700 metres, the highest peak in Kabupaten Sikka. To the east of Egong is Tana 'Ai, which was brought into the Rajadom of Sikka only late in its history. Manggarai is the far western region of Flores.

20 In Wai Brama, inexpensive and shallow white ceramic bowls that serve in quotidian and ceremonial meals are stored in stacks in loosely plaited, cylindrical lontar leaf baskets called kloda. Kloda, and baskets generally, are tropes for the way in which the tana (domain) contains its constituent social groups (see Lewis 1989). Stacks of plates are also referred to as pigang natar ha, 'stack' or 'nest of plates'. The word natar also means 'village', hence pigang natar ha is also a 'village of plates'.

21 The complete name in ritual language of clan Liwu in Tana Wai Brama, the last clan in the order of precedence of the domain's clans, is Liwu Pigan Bitak, 'Liwu of the Shattered Plate(s)'. The origin myth of clan Liwu and the myth that details the clan's incorporation into the society of Tana Wai Brama includes among its episodes the breaking of a stack (natar) of many plates (see Lewis 1988a:123-125). People of Liwu are found in many parts of east central Flores apart from Tana Wai Brama, and it is tempting to see Liwu's myth of the shattered plates as an expression of the diaspora of the clan's members in mythic times, one 'sherd' of which became part of the domain of Wai Brama. In the introductory chapter of the Hikayat, which details the origins of the various peoples of Sikka (Lewis forthcoming, Appendix 2), it is said that an ancestral figure named Késo Kuit originated at Mekeng Detung and formed the clan of Liwu at Kringa, a domain in the northern realm of Tana 'Ai, and at Hikong, a village in Kringa (Lewis forthcoming, Appendix 2). In the ngeng ngérang, the mythic histories of Tana Wai Brama, Késo Kuit was a companion of Hading Dai Dor and Uher La'i Atan, the brothers who founded Tana Wai Brama.

22 See, for example, ten Dam (1950), for an account of Nita written during the later years of Boer's and Kondi's literary careers.

23 In both Sara Sikka and Bahasa Indonesia raja means 'ruler' and in Sara Sikka sina means 'China, Chinese', which is extended to mean any person or thing from the west or north-west in South-East Asia.

24 Lewis (forthcoming), Chapter XII, 'The Second Period: The Middle rajas'.

25 Lewis and Mandalangi (2008:194-196), Section 7.6, 'Mengenai Nita'.

26 Lewis and Mandalangi (2008:262-266), Section 9.2, ‘Nong Méak alias Josef da Silva Menjadi Wakil Raja Sikka'.

27 In the Hikayat's narrative, da Gama arrived in Sikka from Malacca before Alésu's return, but Alésu was responsible for da Gama's dispatch to Flores by Malacca's raja Worilla.

28 Ling (SS) means 'hour (the striking of a clock)' and '(tinkling) sound'; wéling means 'value' or 'price'. The Ata Sikka translate the phrase ling wéling and the synonym bélis into Bahasa Indonesia as 'emas kawin', meaning in the Sikkanese context, 'bridewealth'.

29 Lewis (forthcoming), Chapter X, 'Gifts of Ivory Masts and Sails'.

30 Lewis and Mandalangi (2008:122-127), Section 4.4., 'Don Alésu Menghadiakan dengan Mangung Lajar'.

31 Lewis (forthcoming), Chapter X, 'Gifts of Ivory Masts and Sails'.

32 Lewis and Mandalangi (2008:217-220), Section 8.1, 'Raja Larantuka Meminta Bea; Masalah Gading di Nita'.

33 Lewis and Mandalangi (2008:217-220), Section 8.1, 'Raja Larantuka Meminta Bea; Masalah Gading di Nita'.

34 Lewis and Mandalangi (2008:217-220), Section 8.1, 'Raja Larantuka Meminta Bea; Masalah Gading di Nita'.

35 In fact, this was not entirely the case: a Sikkanese house (including the royal house) in danger of depopulation could keep its daughters and acquire men by arranging marriages without bridewealth. In such marriages, rather than leaving her natal group, a woman remained in her paternal house and her husband changed house affiliation, joining his wife's father's house. Thus commoners occasionally 
became nobles and nobles occasionally became members of the royal house. Retainers were also occasionally 'adopted' by their patrons the term in Sikka Natar is masuk keluarga (BI enter the family) - thereby acquiring the status of free commoners and even nobility. (According to my Sikkanese informants, 'slavery' was abolished after World War Two and all of the maha of Sikka Natar were adopted en masse into the households of their patrons, an event which seems to have caused little disruption in Sikka Natar.) 